\title{
Water Resources of Nicaragua and COVID-19: Between panic and apathy?
}

\author{
K. Vammen ${ }^{a *}$ (1) and S. M. Guillen ${ }^{b}$ \\ ${ }^{a}$ University of Central America - UCA Managua, Institute of Interdisciplinary Research in Natural Sciences, \\ Corresponding Member of the Academy of Science of Nicaragua, Apartado Postal 6117, Managua, Nicaragua

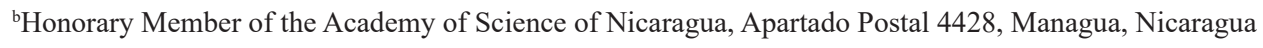 \\ *e-mail: katherine.vammen@uca.edu.ni
}

Received: May 11, 2020 - Accepted: May 19, 2020 - Distributed: August 31, 2020

The severe global problem caused by the appearance and wide dispersion of the corona virus COVID-19 is manifested not only as a problem of public health, but also as an ecological imbalance due to a viral contagion between species of different organisms where the human species has been severely affected. Nature, of which we are an integral part, incorporates in different natural processes the contagion and transmission of the virus in different components of the ecosystem as well as the hydrological cycle, a transversal process functioning for all living beings and many other abiotic natural processes. For this reason, it is important to understand what the associated risks are and how the critical structural degradation of the hydrological resources on a global and national level could exacerbate even more the sanitary crises. In our country, Nicaragua, the deterioration of the watersheds, the loss of water and its good quality has stemmed from a complex and continuous structural problem without the long due concrete and appropriate solutions.

Everyone learned in primary school how the water or hydrological cycle functions: precipitation, infiltration of water to the underground, recharge of aquifers, surface runoff, feeding of lakes and rivers, evaporation transpiration, condensation and again returning to precipitation. As far as the physical natural phenomenon, this process has traditionally been reliable and has conditioned human behavior to the tranquility associated with its compliance as a natural law just like the law of gravity. So we have always believed that water "will always be present, whatever we do".

The Pandemic that we are now living through affects society, the economy, and the environment, and constitutes a different cycle as the natural hydrological cycle: a hydro-illogical cycle, which is caused by human intervention. In this context, a drought caused by the reduction or absence of rain, brings us great concern and anxiety and merges into panic in the climax of the drought, until the first rains come and water brings tranquility and hope which then after reaching stability brings a general situation of apathy toward the cause of the problem as everyone feels that the crisis has been overcome partially. The ghost of the drought has vanished and is forgotten temporarily until little by little the scarcity of water forms a new progressive stage of concern where unfortunately the rhetorical speeches or pleas do not transcend to actions which can mitigate the damage caused and make possible the implementation of an intelligent process of adaptation to the fluctuation of regional climate variability and global climate change.

The social and economic vulnerability of Nicaragua grows to the extent in which the phenomenon of general desertification - product of deforestation, non-sustainable agriculture, and extensive cattle breeding- advances relentlessly over the national geography, in which we are simple spectators. Contrarily to the content of rhetorical declarations, the environmental degradation due to the continuing change in land use in a country which has a forest vocation of $70 \%$ of its territory, makes it impossible for an adequate functioning of the hydrological cycle and causes the disappearance of the natural basic conditions where the moisture condenses in the forests, permits the infiltration to groundwater and feeding of rivers and lakes. It is not possible to induce or permit these drastic changes which break the equilibrium of nature and at the same time still have foolish trust that the cycle of water will continue functioning normally. As we know water cannot be substituted, and due to the reduction of the regimen of precipitation, its effects deeply the agricultural economy and well-being of the population with irreversible environmental impacts.

It is true that the global and regional changes severely modify the patterns and behavior of the economy of water, but in Nicaragua the local causes and effects, associated to the transformations over the ecology in national territory, are proportionally more important. For this reason it is shocking that although we know with detail the causes of the national desertification and we have adopted laws to control and correct these environmental tensors, we continue moaning at the wailing wall and going illogically from panic to apathy without really getting to the root of the problem.

Happily, we do have the capacity to implement in Nicaragua measures of adaptation for climate change on a local level, responsibly correcting the effects caused by the absence of a territorial administration on a national level. It is well known that the environmental factors under tension that are now so common like deforestation, changes in land use, impermeabilization of water recharge 
areas, overexploitation of aquifers, the contamination of waterbodies with solid and liquid wastes, the abuse in the application of toxic agrochemicals ... are the cause of hydric and wind erosion, the reduction of groundwater, the loss of water quality, the decrease in water flows and even the disappearance of water sources. The need to develop capacities to manage water behavior, once it arrives at the surface of the territory, is the objective of the Integrated Water Resource Management (IWRM) defined by the Technical Committee of the Global Water Program (GWP) as "a process which promotes the management and coordinated development of water, land and related resources, in order to maximize social and economic wellbeing in an equitable manner, without compromising the sustainability of ecosystems."

The Law N ${ }^{\circ} 620$, General Law of Nacional Waters (Nicaragua, 2007) of Nicaragua defines the integral management of watersheds as:

A set of regulatory, administrative, operational and control activities which should be carried out by the State and society to guarantee the sustainable development and the optimal quality of life of the inhabitants of each hydrographic watershed, on the one hand; and on the other hand, emphasize conservation which will promote the sustainable use of soils, water and forests [sic] and other associated resources and environment.

What are the necessary actions that have been anticipated to cut the Gordian knot?

The essential function of Law 620 is to confront the vicious culture of laissez-faire, responsible for the vacuum of water management, governance and administration of water, whose effects have been discussed in this article. These concepts and mandates are part of the content of the second title of said law which due to its relevance to this topic, we will reproduce partially here:

The Guiding Principals of Water Resources: Knowledge. Knowledge of the country's water resource is a high priority for the State, as an indispensable element for the sustainable management of the resource.

Integral Management: Water management is based on the integral management of surface and underground basins, the multiple use of water and the interrelation that exists between the resource and air, soil, flora, fauna, and biodiversity.

The Instruments of Management: The National Water Resources Information System. Principally comprised of geographical, meteorological, hydrological, hydrogeological information and includes the management of data banks, the operation and maintenance of networks and the dissemination of the obtained information. Still an unresolved task.

Water Planning: The elaboration and integration of water planning will also take into account the necessary criteria to guarantee the sustainable beneficial use and the integral use of the water resources of the hydrographical watersheds and aquifers as management units. Water planning involves the elaboration of the National Plan for Water Resources by the national authority of water, which should serve as the basis for preparing plans and programs by basin, under the responsibility of the Basin Organizations. Still another unresolved task (General Law of Water of Nicaragua, 2007).

All the previous shows that according to the Law 620 , the generation of knowledge on water resources and its adequate dissemination forms the basis for understanding the physical- natural processes which operate in each territory, part of the national hydrographical watersheds, organized into the National Water Resources Information System. This demands that the governance or integrated management of water resources forms part of the process of planning and implementation of the National Plan of Water Resources. Both instruments although they have been foreseen for 13 years continue as pending tasks despite being our life savers against poverty and essential for survival. Clearly they are essential and even more urgent in order to benefit rationally from the cycle of water in Nicaragua and protect the operation of the water factories on a local level and present in the watersheds on which the well-being of society and the national economy depend, in an environmentally sustainable way.

What has been expressed above is fundamental to explain that Nicaragua has the legal tools and framework and technical previsions necessary to implement useful plans in the use and protection of its watersheds for many years, the objective of which is to correct the inappropriate usage of the soils that has made our territories more vulnerable to the effects of variability and climate change. It is not enough to just reforest but to plan and implement together (State, civil society, academia and all the actors involved) in the development of appropriate integral plans appropriate to the conditions of each watershed that corrects all the problems caused upon nature and with goals of social, economic and environmental utility in a sustainable manner: water for all uses and for all users.

These considerations are essential to understand that the availability of water for personal hygiene is essential for the prevention and treatment of the pandemic virus and other structural disorders such as childhood gastroenteritis and other diseases associated with poor hygiene and causing high national morbidity and mortality. These measures of prevention and the treatment of these ailments depend on the restoration of nature and the correct functioning of the national hydrographical watersheds.

\section{The Need for Water to Confront the Pandemic of COVID-19}

The most important resource needed to confront the pandemic of COVID-19 is water. It is the fundamental means to maintain hospital, domestic and work hygiene that contributes to the wellbeing and health of the population. From hand washing to disinfection of surfaces, this resource is the most essential element to maintain sanitary conditions in all environments. For this reason, maintaining the continuing access to potable water with the necessary hygienic quality is essential in these times of Pandemic of COVID-19. 
The access to safe water in the dry season (November to May) has always been a challenge in Nicaragua in the last decades and recently there have been many reports on critical problems especially from the areas of the dry corridor in many rural communities and peri-urban zones. It is not only a problem of having enough but also having access to good quality water especially now with the great need for microbiological quality to secure good sanitary conditions. The purification and disinfection of water has been converted into a primary factor to impede the transmission of the virus and contagion in all countries of the world.

Of course this goes hand in hand with the need for a continuing supply of electrical energy to secure the associated services which guarantee access and also the treatment of water (pumping of groundwater, purification and treatment, services needed to guarantee continuing supply and distribution and more).

The treatment of wastewaters in urban and rural zones is also fundamental in securing a hygienic environment for the population.

\section{COVID-19 and Water}

The coronavirus 2 of the severe acute respiratory syndrome (SARS-CoV-2) is an enveloped virus. This type of virus wrapped in an envelope of bilipid membranes is considered less stable under environmental conditions. Its transmission occurs through direct contact with an infected person through respiratory droplets (bioaerosols-generated by coughing, sneezing or through talking), deposits on surfaces (i.e., fomites) and the contamination of hands, which then expose the mucus membrane of the nose or throat. The transmission through direct ingestion has not been observed but is now under investigation. It is known that SARS-CoV-2 is less persistent in water than most enteric viruses and enveloped viruses are more susceptible than other viruses to chemical inactivation for example with chlorine-based solutions and other disinfectants; also deactivation through exposition to ultraviolet light has been observed (Wigginton and Boehm, 2020). The methodologies used to secure water adequate for human consumption have taken into account the elimination of viruses even more robust than COVID-19 (IWA, 2020); their elimination has also been considered in standard water treatment processes.

Enveloped viruses have a lipid membrane which surrounds a protein capsule that consists of protein and glycoprotein. The surface chemical active groups in the external membrane are probably what influence most their survival and behavior in aquatic environments. (Arbely et al., 2006; Shigematsu et al., 2014; Gundy et al., 2009). Free chlorine can penetrate the membrane of lipids without problems reacting with internal proteins to inactivate them (Ye et al., 2018).

Viruses that are transmitted directly person to person or through drops of water through the respiratory via typically do not survive very long outside of their hosts in the environment, but the transmissions of the virus can take place through aerosols or by contact with water, food and surfaces if they can survive long enough to make contact with a new host (Ye et al., 2018).

However, the continuing excretion of the virus could have importance for public health as the transmission to other persons is through bioaerosols or the contamination from surfaces and for this reason, contaminated waters that contain coronavirus are a potential vehicle for exposition, as long as aerosols are produced (Hung, 2003; Casanova et al., 2009). There is still a great need for generating more knowledge about the persistence of SARS-CoV-2 in different compartments of the environment and especially about their mechanisms of inactivation

According to the last study of the World Health Organization and the United Nations Children's Fund (OMS, 2017) 52\% of the population of Nicaragua had access to safely managed drinking water in 2017; in urban zones $67 \%$ and in rural areas only $29 \%$. It is important to add that $42 \%$ of the Nicaraguan population live in rural areas.

The term "safely managed drinking water" originates from the Sustainable Development Goals (SDG) and is the indicator of Target 6.1 (Achieve access to safe and affordable drinking water) which specifies "Drinking water from an improved water source that is located on premises, available when needed and free from fecal and priority chemical contamination" (United Nations, 2018).

The COVID-19 pandemic has shown the importance of disinfection at the optimal dose in systems of potable water to protect public health. It has been demonstrated that coronavirus can enter into a system of distribution of potable water if the residual amount of disinfectant is at a low concentration. It is suspected that the stability of the virus could continue through the colonization of bacteria that are present in biofilms in the piping system and in this way enter into individual houses through transmission as aerosolization from showers (Naddeo and Liu, 2020).

As has been observed globally the majority of hotspots of the COVID-19 has been in urban centers such as Wuhan, Milan, Madrid, Nueva York, São Paulo, Guayaquil and the list is growing. It is a fact that infectious diseases in the majority originate in urban centers due to the high density of population in less space. It is well known that in the last years there has also been many infectious outbreaks of virus in urban centers, as SARS in 2003 and ZIKA in the Americas (Lee et al., 2020). And these urban centers now are becoming conduits of transmission globally and nationally according to the connections of the different external and internal transport connection systems.

There is casual evidence and research in progress that suggests at least the possibility that wastewater and feces contaminated waters could serve as vector media for enveloped viruses including the Corona classes of virus. (Holshue et al., 2020). As pointed out in a study of the challenges to management of urban waters in the Americas (IANAS, 2015) special attention should be paid to wastewaters in peri-urban areas and new urban development areas as these are well known to have more overflow and accumulation of waste waters in the streets and in open drainage systems or open gutter ditches. 


\section{COVID-19 in waste waters: State of waste waters in Nicaragua}

Viruses are connected to waste waters since some originate in feces and urine of infected humans. Studies have shown that coronavirus could stay viable in waste waters, especially those that arise from hospitals and other areas with a high density of people (Hung, 2003; Leung et al., 2003). There have also been observations that mention a certain persistence of viruses of this kind in aquatic environments and wastewater treatment plants (Fong and Lipp, 2005; Casanova et al., 2009). But still the question is open how long the coronavirus can persist and be infectiously active in waste waters.

Until now, investigations on enveloped viruses in waste waters have indicated that they are inactivated faster than non-enveloped viruses (Brainard et al., 2017), that they adhere more to solids and the temperature is associated to the rate of inactivation (Ye et al., 2016). Still it is important to note that enveloped viruses are extremely diverse and therefore have a high range of pathogenicity and cycles of replication (Wigginton and Boehm, 2020); thus they have a great diversity of behavior, persistence and fate in the environment (Aquino de Carvalho et al., 2017).

It is now essential to develop more studies on the specific capacity of virus survival in feces and urine in order to better understand its exact route in the cycle towards the environment and especially their deposition and behavior in wastewater treatment. Recent studies reported detection of RNA from SARS-CoV-2 in feces (Holshue et al., 2020) and urine (Peng et al., 2019) of infected people. Another study indicated that SARS-CoV-2 could survive some days in appropriate environments, after passing through the human body (Mao et al., 2020).

Research carried out after the epidemic of SARS in 2003 found traces of the virus in wastewaters, that were able to survive due to the absence of adequate disinfection, which increased the potential of contagion of the virus (Leung quoted in Naddeo and Liu, 2020). There are still limited data about the concentration of enveloped viruses in feces and urine. The coronavirus responsible for the Epidemic of SARS in 2003 replicated in the digestive tract of humans and infectious particles were found in samples of feces.

Viruses are normally found concentrated in suspended solids in the wastewater treatment plants and can be removed efficiently with filtration systems as a bioreactor in combination with antagonist microorganisms and adverse physical chemical conditions to inactivate the enveloped viruses (Bodzek et al., 2019; Chaudry and Nelson, 2015).

The genes of coronavirus have been detected in feces of infected individuals (Jevsnik et al., 2013; Poon et al., 2004; To et al., 2010) as well as in biosolid remnants of waste waters (Bibby and Peccia, 2013). Some enveloped viruses can survive some days and even weeks in pasteurized wastewaters (Bibby et al., 2015; Casanova and Weaver, 2015). Based on these results, it is possible that wastewaters and feces contaminated waters could serve as a vector medium for certain enveloped viruses (Ye et al., 2018).
We mention here the case of the coronavirus SARS in an apartment building in Hong Kong where the transport of wastewater to the air duct systems probably contributed to the diffusion of virus in fecal aerosolized particles (Hung, 2003).

There are studies on the behavior of enveloped viruses in wastewaters that indicate that they inactivate faster than other virus; however their survival even for a limited time is motive for concern and indicates that attention must be paid to wastewater treatment plants, overflow of waste waters into unchecked areas and potential intrusion into supplies of potable water (Yu et al., 2004).

At this time, there exists initiatives to monitor wastewater treatment plants for the presence of COVID-19 as an early warning system for communities in order to verify if the virus has returned after a period of reduction of infections. This has been named "wastewater-based epidemiology" (WBE) and has significance for the future to introduce tracing and control of potential pathogenic infections that could threaten public health (Mao et al., 2020).

Traces of the virus or RNA have been found in wastewaters in Holland, United State and Sweden (Mallapaty, 2020). For example, traces of SARS-CoV-2 were detected in wastewaters of the airport Tilburg, four days after the first case was detected in Holland. If it proves to be functional, the results of this type of monitoring could produce better statistics that would also include people that have not submitted diagnostic tests for COVID-19. There is still missing information about how much RNA of the virus is excreted into feces; this would make it possible to calculate the number of infected people present in the population. With a more advanced development of the methodology and necessary information to carry out sampling and the analyses of results, this type of monitoring could be a source of information to introduce such measures as domestic quarantines in communities and urban centers (Mallapaty, 2020). This type of monitoring of wastewaters has already been used in the past to analyze the success of vaccination campaigns for the virus of poliomyelitis.

There still exists a vacuum of information about the transmission of the virus in environmental exposition routes including water and wastewaters. The pandemic of COVID-19 has shown the need for research about these routes and other details of the survival of the virus in these media.

It should be noted that vias of exposition exist where the deficient management of wastewaters predominate, which are released to the streets in rural communities and peri-urban areas in Nicaragua, where there is not adequate coverage of sewage systems and treatment of wastewaters or where there is deficient and failed infrastructure in the systems of distribution and plumbing.

\section{Sanitation and Coverage of Treatment Wastewaters in Nicaragua}

"The immediate cause of increasing water pollution is the growth in wastewater loadings to rivers and lakes. Ultimate causes are population growth, increased economic 
activity, intensification and expansion of agriculture and increased sewerage hook-ups with no or a low level of treatment" (UNEP, 2016).

To secure the health of the population, it is fundamental to pay attention to the coverage of sanitation and the initiatives to improve the treatment of wastewaters.

"The deterioration in the quality of water can affect the health of the population in Nicaragua especially due to contamination through pathogens that affect the hygienic quality of water...." (IANAS, 2019).

\section{Present situation in urban centers and rural areas of Nicaragua}

According to the latest report from WHO and UNICEF (2019), Nicaragua has raised the coverage of the population using improved sanitation facilities specifically sewer connections from $16 \%$ in 2000 to $24 \%$ in 2017 ; in urban areas from $29 \%$ to $41 \%$ and in rural areas still no improvement $<1 \%$. Open defecation has been lowered on a national level from $16 \%$ in 2000 to $7 \%$ in 2017 ; whereas in urban areas almost eliminated from $4 \%$ to $<1 \%$ but in rural areas from $30 \%$ in 2000 and still maintaining 14\% in 2017.

Although up to date figures have not been published about the coverage of sanitation, there is information about initiatives to improve sanitation in urban centers which indicate improvements in progress. It is important to mention that the Integral Sectorial Program of Water and Human Sanitation (PISASH-for Spanish name, Programa Integral Sectorial de Agua y Saneamiento Humano) has promoted programs of water and sanitation executed by the Nicaraguan Company of Aqueducts and Sanitary Sewers (ENACAL) since 2014. The program has advanced in the installation and renovation of treatment plants and sewage systems in 14 urban centers with populations of more than 5000 inhabitants and a second phase of the program is in planning.

The situation of health of the rural population is affected by the absence of sanitation and as mentioned the still existing practice of open defecation in many communities and country settlements. The level of sanitation in rural areas is still based mainly on the most basic mode of use of latrines and other similar installations.

Target 6.2 of the Sustainable Development Goals states: Achieve access to sanitation and hygiene and end open defecation. Taking into account that Nicaragua still has $14 \%$ of the rural population practicing open defecation, it is urgent to establish more progress in designs and specific plans for rural zones with the objective of increasing the coverage of better sanitation in these communities.

\section{Conclusions and Recommendations for Nicaragua}

The emergence of the viral pandemic that we are now living through is the result of the imbalance in the relationship between humanity and nature whose natural processes have been severely intervened and deteriorated. It is of particular importance the state of water resources whose process is under increasing tensions due to global climate change and the national degradation of water basins. Due to this, the reduction in quantity and quality of water resources is affecting society, the economy, the environment and of course with that our future and survival on the planet.

The spread of the contagion has been facilitated due to the millions of flights of people traveling throughout the planet, especially to dense human populations in large urban centers and the apathy that prevents the application of adequate measures and opportunities to prevent the contagion. The resulting panic should only be the beginning of the organization of measures to restrain and solve the contagion.

The known hidro-illogical human cycle, of panic due to severe droughts and then apathy as the rains initiate is very similar to the observed human behavior at this moment concerning the pandemic: panic due to the high risk of the contagion and the deaths and then lowering the guard after the progressive decrease of the number of infected cases.

It has been observed that water is the most important resource to impede the continuation of the infections in urban centers and human settlements globally. It is urgent to prioritize efforts, especially for the responsible authorities, to secure the access to water of good quality with microbiological criteria for human consumption in urban centers and rural areas of Nicaragua. Immediate actions should be introduced to secure the supply of water where there are no existing services of potable water managed in a safe manner and if needed in mobile containers or other means where water can be securely stored and transported. It is important to emphasize the correct adequate doses of residual chlorine to securely disinfect the water in the complete distribution system.

In the medium term, it should be of priority the rapid continuation of the development of programs destined to secure the wider coverage of sewage systems and treatment of waste waters in all the national territory of Nicaragua accompanied by a program of evaluation and follow up on the appropriate functioning of the Waste Water Treatment Plants to evaluate the needs for replacement or reform.

It is urgent to introduce measures in rural zones of Nicaragua to establish systems of treatment of waste waters adapted to present local conditions to eradicate open defecation in Nicaragua, as this affects the health of the population causing diverse diseases.

The crisis of COVID-19 is tied to and is complicated by the climatic-environmental crisis which Nicaragua has been subjected to since decades with its own multiplicative effects. For this reason, the response measures cannot be only of a hygienic-sanitary character, but necessarily need to include environmental factors. The crisis brings in new tensions and causes to the ecosystem imbalance which will be exacerbated and in turn negatively affecting the abundance of the national water resources and their basins who previously were already under severe degradation and desertification. Although there are planned solutions, 
approved as laws but deficient in their application, it has been evidenced that the highest priority is the need to deepen the knowledge on water resources and specify the adequate integral management of soils, flora, fauna and biodiversity through water planning for surface- and groundwater and the implementation of the appropriate plans.

\section{Acknowledgements}

This article in part was an essay published in a recent publication of the Academy of Sciences of Nicaragua in Spanish: COVID-19, el caso de Nicaragua. Aportes para enfrentar la pandemia.

\section{References}

AQUINO DE CARVALHO, N., STACHLER, E.N., CIMABUE, N. and BIBBY, K., 2017. Evaluation of Phi6 Persistence and Suitability as an Enveloped Virus Surrogate. Environmental Science \& Technology, vol. 51, no. 15, pp. 8692-8700. http:// dx.doi.org/10.1021/acs.est.7b01296. PMid:28657725.

ARBELY, E., GRANOT, Z., KASS, I., ORLY, J. and ARKIN, I.T., 2006. A trimerizing GxxxG motif is uniquely inserted in the severe acute respiratory syndrome (SARS) coronavirus spike protein transmembrane domain. Biochemistry, vol. 45, no. 38, pp. 11349-11356. http://dx.doi.org/10.1021/bi060953v. PMid:16981695.

BIBBY, K. and PECCIA, J., 2013. Identification of viral pathogen diversity in sewage sludge by metagenome analysis. Environmental Science \& Technology, vol. 47, no. 4, pp. 1945-1951. http://dx.doi. org/10.1021/es305181x. PMid:23346855.

BIBBY, K., FISCHER, R.J., CASSON, L.W., STACHLER, E., HAAS, C.N. and MUNSTER, V.J., 2015. Persistence of Ebola virus in sterilized wastewater. Environmental Science \& Technology, vol. 2, no. 9, pp. 245-249. http://dx.doi.org/10.1021/ acs.estlett.5b00193. PMid:26523283.

BODZEK, M., KONIECZNY, K. and RA, M., 2019. Membranes in water and wastewater disinfection [review]. Archives of Environmental Protection, vol. 45, pp. 3-18.

BRAINARD, J., POND, K. and HUNTER, P.R., 2017. Censored regression modeling to predict virus inactivation in wastewaters. Environmental Science \& Technology, vol. 51, no. 3, pp. 17951801. http://dx.doi.org/10.1021/acs.est.6b05190. PMid:28051304.

CASANOVA, L., RUTALA, W.A., WEBER, D.J. and SOBSEY, M.D., 2009. Survival of surrogate coronaviruses in water. Water Research, vol. 43, no. 7, pp. 1893-1898. http://dx.doi.org/10.1016/j. watres.2009.02.002. PMid:19246070.

CASANOVA, L.M. and WEAVER, S.R., 2015. Inactivation of an enveloped surrogate virus in human sewage. Environmental Science \& Technology, vol. 2, pp. 76-78.

CHAUDRY, R.M. and NELSON, K.L., 2015. Environmental Science \& Technology, vol. 49, pp. 2815-2822. http://dx.doi. org/10.1021/es505332n.

FONG, T.T. and LIPP, E.K., 2005. Enteric viruses of humans and animals in aquatic environments: Health risks, detection, and potential water quality assessment tools. Microbiology and Molecular Biology Reviews, vol. 69, no. 2, pp. 357-371. http:// dx.doi.org/10.1128/MMBR.69.2.357-371.2005. PMid:15944460.
GUNDY, P.M., GERBA, C.P. and PEPPER, I.L., 2009. Survival of coronaviruses in water and wastewater. Food Environ, vol. 1, no. 1, pp. 10-14. http://dx.doi.org/10.1007/s12560-008-9001-6.

HOLSHUE, M.L., DEBOLT, C., LINDQUIST, S., LOFY, K.H., WIESMAN, J., BRUCE, H., SPITTERS, C., ERICSON, K., WILKERSON, S., TURAL, A., DIAZ, G., COHN, A., FOX, L., PATEL, A., GERBER, S.I., KIM, L., TONG, S., LU, X., LINDSTROM, S., PALLANSCH, M.A., WELDON, W.C., BIGGS, H.M., UYEKI, T.M. and PILLAI, S.K. 2020. First Case of 2019 Novel Coronavirus in the United States. The New England Journal of Medicine, vol. 382, no. 10, pp. 929-936. http://dx.doi. org/10.1056/NEJMoa2001191. PMid:32004427.

HUNG, L.S., 2003. The SARS epidemic in Hong Kong: what lessons have we learned? Journal of the Royal Society of Medicine, vol. 96, no. 8, pp. 374-378. http://dx.doi.org/10.1177/014107680309600803. PMid:12893851.

INTERNATIONAL WATER ASSOCIATION - IWA, 2020 [viewed 8 April 2020]. COVID-19: A Water Professional's Perspective, Panel Discussion [online]; London, United Kingdom: IWA. Available from: https://iwa-network.org/learn/covid-19-a-waterprofessionals-perspective/

JEVSNIK, M., STEYER, A., ZRIM, T., POKORN, M., MRVIČ, T., GROSEK, Š., STRLE, F., LUSA, L. and PETROVEC, M., 2013. Detection of human coronaviruses in simultaneously collected stool samples and nasopharyngeal swabs from hospitalized children with acute gastroenteritis. Virology Journal, vol. 10, no. 1, pp. 46-52. http://dx.doi.org/10.1186/1743-422X-10-46. PMid:23379823.

LEE, V.J., HO, M., KAI, C.W., AGUILERA, X., HEYMANN, D, and WILDER-SMITH, A., 2020. Epidemic preparedness in urban settings: new challenges and opportunities. Lancet, vol. 20, no. 5, pp. 527-529. http://dx.doi.org/10.1016/S1473-3099(20)30249-8. PMid:32224312.

LEUNG, W.K., TO, K., CHAN, P.K.S., CHAN, H.L.Y., WU, A.K.L., LEE, N., YUEN, K.Y. and SUND, J.J.Y., 2003. Enteric involvement of severe acute respiratory syndrome-associated coronavirus infection. Gastroenterology, vol. 125, no. 4, pp. 1011-1017. http://dx.doi.org/10.1016/j.gastro.2003.08.001. PMid:14517783.

NICARAGUA, 2007 [viewed 8 April 2020]. Ley General de Aguas Nacionales de 2007, La Gaceta $\mathrm{n}^{\circ}$ 169, 15 de mayo de 2007 [online]. La Gaceta, Diario Oficial, 04 de sept. Available from: ttp://legislacion.asamblea.gob.ni/Normaweb.nsf/(\$All)/ C0C1931F74480A55062573760075BD4B

MALLAPATY, S., 2020. How sewage could reveal true scale of coronavirus outbreak. Nature, vol. 580, no. 7802, pp. 176-177. http://dx.doi.org/10.1038/d41586-020-00973-x. PMid:32246117.

MAO, K., ZHANG, H. and YANG, Z., 2020. Can a Paper/ Based Device Trace COVID-19 Sources with Wastewater-Based epidemiology? Environmental Science \& Technology, vol. 54, no. 7, pp. 3733-3735. http://dx.doi.org/10.1021/acs.est.0c01174. PMid:32202421.

NADDEO, V. and LIU, H., 2020. Editorial Perspectives: 2019 novel coronavirus (SARS-CoV-2): what is its fate in urban water cycle and how can the water research community respond? Environmental Science: Water Research \& Technology. vol. 6, pp. 1213-1216. http://dx.doi.org/10.1039/d0ew90015j

PENG, L., LIU, J., XU, W., DENG, K., LIN, B. \& GAO, Z. 2019. Novel Coronovirus can be detected in urine, blood, anal swabs and oropharyngeal swabs samples. Preprint Medrxiv. http://dx.doi. org/10.1101/2020.02.21.20026179 
POON, L.L.M., CHAN, K.H., WONG, O.K., CHEUNG, T.K.W., NG, I., ZHENG, B., SETO, W.H., YUEN, K.Y., GUAN, Y. and PEIRIS, J.S.M., 2004. Detection of SARS coronavirus in patients with severe acute respiratory syndrome by conventional and real-time quantitative reverse transcription-PCR assays. Clinical Chemistry, vol. 50, no. 1, pp. 67-72. http://dx.doi.org/10.1373/ clinchem.2003.023663. PMid:14709637.

ORGANIZACIÓN MUNDIAL DE LA SALUD - OMS and FONDO DE LAS NACIONES UNIDAS PARA LA INFANCIA - UNICEF, 2017 [viewed 8 April 2020]. Progresos en materia de agua potable, saneamiento e higiene [online]. Copenhague: OMS. Available from: https://www.who.int/water_sanitation_health/ publications/jmp-2017/es/

SHIGEMATSU, S., DUBLINEAU, A., SAWOO, O., BATEJAT, C., MATSUYAMA, T., LECLERCQ, I. and MANUGUERRA, J., 2014. Influenza A virus survival in water is influenced by the origin species of the host cell. Viruses, vol. 8, no. 1, pp. 123-130. PMid:24112132.

THE INTER-AMERICAN NETWORK OF ACADEMIES OF SCIENCES - IANAS, 2015 [viewed 8 April 2020]. Urban Water Challenges in the Americas: A perspective from the Academies of Science [online]. México: IANAS Available from: https://www. ianas.org/docs/books/Urban_Water.html

THE INTER-AMERICAN NETWORK OF ACADEMIES OF SCIENCES - IANAS, 2019 [viewed 8 April 2020]. Water Quality in the Americas. Risks and Opportunities [online]. México: IANAS. Available from: https://www.ianas.org/images/books/wb10d.pdf

TO, K.K.W., CHAN, K.H., LI, I.W.S., TSANG, T.Y., TSE, H., CHAN, J.F.W., HUNG, I.F.N., LAI, S.T., LEUNG, C.W., KWAN, Y.W., LAU, Y., NG, T., CHENG, V., PEIRIS, J. and YUEN, K., 2010. Viral load in patients infected with pandemic H1N1 2009 influenza A virus. Journal of Medical Virology, vol. 82, no. 1, pp. 1-7. http://dx.doi.org/10.1002/jmv.21664. PMid:19950247.

UNITED NATIONS (2018). Sustainable Development Goal 6-Synthesis Report on Water and Sanitation. UN Water, New York, USA.

UNITED NATIONS ENVIRONMENT PROGRAMME - UNEP, 2016 [viewed 8 April 2020]. A Snapshot of the World's Water Quality: Towards a Global Assessment [online]. Nairóbi, Quênia: UNEP. Available from: https://uneplive.unep.org/media/docs/ assessments/unep_wwqa_report_web.pdf

WIGGINTON, K.R. and BOEHM, A.B., 2020. Environmental Engineers and Scientists have important roles to play in stemming outbreaks and pandemics caused by enveloped viruses. Environmental Science \& Technology, vol. 54, no. 7, pp. 3736-3739. http://dx.doi. org/10.1021/acs.est.0c01476. PMid:32207922.

YE, Y., CHANG, P.H., HARTERT, J. and WIGGINTON, K.R., 2018. Reactivity of enveloped virus genome, proteins, and lipids with free Chlorine and $\mathrm{UV}_{254}$ Environmental Science \& Technology, vol. 52, no. 14, pp. 7698-7708. http://dx.doi.org/10.1021/acs. est.8b00824. PMid:29886734.

YE, Y., ELLENBERG, R.M., GRAHAM, K.E. and WIGGINTON, K.R., 2016. Survivability, Partitioning, and Recovery of Enveloped Viruses in Untreated Municipal Wastewater. Environmental Science \& Technology, vol. 50, no. 10, pp. 5077-5085. http:// dx.doi.org/10.1021/acs.est.6b00876. PMid:27111122.

YU, I.T.S., LI, Y., WONG, T.W., TAM, W., CHAN, A.T., LEE, J.H.W., LEUNG, D.Y.C. and HO, T., 2004. Evidence of airborne transmission of the severe acute respiratory syndrome virus. The New England Journal of Medicine, vol. 350, no. 17, pp. 17311739. http://dx.doi.org/10.1056/NEJMoa032867. PMid:15102999. 